\title{
Terrorism, Asylum, and Exclusion from International Protection
}

\author{
James C. Simeon
}

Terrorism and asylum have been two of the most pressing issues of our time. They have preoccupied public international law and, specifically, international humanitarian law and international criminal law as well as international human rights and international refugee law. Not to mention the United Nations, regional organizations, and, of course, nation-states, for decades, but, obviously, most decidedly since September 11, 2001 or $9 / 11$, that forever changed the course of modern history and everyone's life. ${ }^{1}$ This edited collection seeks to examine both of these concepts and how they are inter-related and have impacted the course of public policy and, especially, migration policy, that is, asylum and refugee law and practice, across a number of Western liberal democracies, principally, in Europe and North America.

What follows in this introduction is a review of the background and context of these two highly charged and emotive terms. It considers the direct and indirect relationship between these two terms through their predominately common origins in protracted armed conflict, particularly of a non-international character or intrastate conflict. It goes on to analyse briefly the relationship between these two terms. It then provides a brief summary of some of the main arguments presented in each of the contributions to this edited volume and offers a number of conclusions.

The purpose of this edited collection is to make a contribution to the literature that covers both terrorism and asylum, that are largely quite separate and

1 Jon Henley, "Was 9/11 the day that changed the world forever?" The Guardian, September 9, 2011, https://www.theguardian.com/world/2011/sep/og/9-11-changed-world-forever. (accessed July 31, 2019); Laura Santhanam and Larisa Epatko, "9/11 to today: Ways we have changed," PBS News Hour, September 11, 2018, https://www.pbs.org/newshour/nation/911-to-today-ways-we-have-changed. (accessed July 31, 2019); Jennie Wood, "How We've Changed Since 9/11," Infoplease, undated, https://www.infoplease.com/us/government/howweve-changed-since-911. (accessed July 31, 2019); Kent Roach, The 9/11 Effect: Comparative Counter-Terrorism. (Cambridge: Cambridge University Press, 2011). 
distinct. Despite the overwhelming evidence that indicates that they have common origins in organized extreme political violence. Protracted armed conflict and severe political oppression produce terrorism and refugees and until and unless we address these "root causes" both terrorism and refugees will remain at the forefront of all our public international concerns.

\section{$2 \quad$ Background and Context}

Since the horrific events of September 11, 2001, the international community and the United States, specifically, have been preoccupied with the issue of terrorism. The events of $9 / 11$ will forever be etched indelibly in the minds of all those who experienced that day. ${ }^{2}$ It was the worst terrorist attack in modern history. ${ }^{3}$ The aftermath of these four coordinated terrorist attacks that felled the Twin Towers of the World Trade Centre in New York City; destroyed a whole section of the Pentagon in Washington, DC; and, through the heroic actions of the passengers of United Airlines 93, brought down their hijacked airliner in Shanksville, Pennsylvania, killing all those on board, that was targeted, ostensibly, to strike the US Capitol Building, in Washington, DC, was to change inconvertibly the world forever. ${ }^{4}$

A shocked and terrorized world responded through the United Nations calling on all states to bring the perpetrators of $9 / 11$ to justice, while the United

2 Dana Rose Garfin, "How the pain of 9/11 still stays with a generation," The Conversation, September 9, 2016, updated September 11, 2016, https://theconversation.com/how-the-pain-of9-11-still-stays-with-a-generation-64725. (accessed September 15, 2018); Carlin Crisanti and Jennifer Merolla, "The Effects of the 9/11 Terrorist Attacks on American Public Opinion and Behavior," Oxford Bibliographies, last modified 27 February 2019, http://www.oxfordbibliographies.com/abstract/document/obo-9780199756223/obo-9780199756223-0270.xml?rskey=mD rMWf\&result $=5 \& q=$ Counterterrorism\#firstMatch. (accessed March 24, 2019)

3 Benjamin Elisha Sawe, "Worst Terrorist Attacks in World History," worldatlas, April 25, 2017, https://www.worldatlas.com/articles/worst-terrorist-attacks-in-history.html. (accessed March 16, 2019)

4 Helaina Hovitz, "I was 12 years old and blocks away from the World Trade Centre on 9/11 here's how I saw the world change around me forever," Business Insider, September 11, 2018, https://www.businessinsider.com/911-completely-changed-the-world-as-we-knew-it-hereshow-2018-9. (accessed September 15, 2018); Meagan Smith, Sean M. Zeigler, "Terrorism before and after 9/11 - a more dangerous world?" Research \& Politics, November 10, 2017, pp. 1-8, http://journals.sagepub.com/doi/pdf/10.1177/2053168017739757. (accessed September 15, 2018); Satvinder S. Juss, ed., Beyond Human Rights and the War on Terror. (London: Routledge, 2019). Manfred Nowak and Anne Charbord, eds., Using Human Rights to Counter Terrorism. (Cheltenham, UK: Edward Elgar Publishing, 2018) 
States announced it would undertake a "War on Terror." Within a month, the United States and its coalition partners invaded Afghanistan to dismantle Al Qaeda and to deny it a safe base of operations under the radical fundamentalist Taliban regime. Sadly, the "War in Afghanistan" that commenced on October 7,2001 , is still ongoing today. Contentious from the very outset, the "War on Terror," has undergone various permutations and has been renamed the "Over-

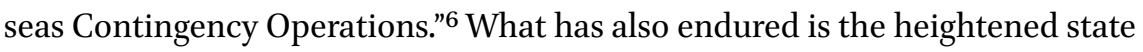
of security and the resolve that no other terrorist attack like 9/11 will ever occur again. This has often been described as "securitization."7 The preoccupation with national security concerns and, more specifically, the prevention of terrorism, that has resulted in an increase in monitoring and surveillance and intelligence gathering with, ineluctably, a commensurate diminution in individual privacy and liberty. ${ }^{8}$

Despite all of the efforts on the part of the United Nations and its member states, terrorism has not decreased since $9 / 11$, but, on the contrary and counter intuitively, it has increased over time even though there has been yearly ebbs and flows in the number of terrorist incidents and deaths due to terrorist attacks. ${ }^{9}$

When examining the drivers of terrorism the presence of armed conflict, political violence by governments, political exclusion and group grievances remain critical factors. The analysis finds that 99 per cent of all deaths over the last 17 years has been in countries that are either in

5 United Nations Security Council Resolution 1368, 12 September 2001, http://www.un.org/en/ ga/search/view_doc.asp?symbol=S/RES/1368\%282001\%29. (accessed September 15, 2018); United Nations Security Council Resolution 1373, 28 September 2001, https://www.unodc .org/pdf/crime/terrorism/res_1373_english.pdf. (accessed September 15, 2018)

6 Overseas Contingency Operations, Department of Defense - Military Programs, https:// www.whitehouse.gov/wp-content/uploads/2018/02/o8_OCO_508.pdf. (accessed September 9, 2018) GAO, US Government Accountability Office, Overseas Contingency Operations: Alternatives Identified to the Approach to Fund War-Related Activities, GAO-19-211, January 28, 2019, https://www.gao.gov/products/GAO-19-211. (accessed April 20, 2020)

7 Rens van Munster, "Securitization," Oxford Bibliographies, last reviewed 19 September 2014, http://www.oxfordbibliographies.com/view/document/obo-9780199743292/obo9780199743292-0o91.xml. (accessed March 24, 2019)

8 Matt McDonald, "Securitization and the Construction of Security," European Journal of International Relations, 14:4 (2008), http://wrap.warwick.ac.uk/1232/1/WRAP_McDonald_0671572pais-270709-mcdonald_securitisation_and_construction_of_security_ejir_forthcoming_2008.pdf. (accessed September 15, 2018); Guy S. Goodwin-Gil, "Forced Migration: Refugees, Rights and Security," in Forced Migration, Human Rights and Security. Ed., Jane McAdam (Oxford: Hart Publishing, 2008).

9 Global Terrorism Index 2017, Measuring and understanding the impact of terrorism, Institute for Economics and Peace (IEP), November 2017, IEP Report 55, p. 3. http://visionofhumanity .org/app/uploads/2017/11/Global-Terrorism-Index-2017.pdf. (accessed March 18, 2019) 
conflict or have high levels of political terror. Political terror involves extrajudicial killings, torture and imprisonment without trial. This shows that the great majority of terrorism is used as a tactic within an armed conflict or against repressive political regimes. It also demonstrates the risks of political crackdowns and counterterrorism actions that can exacerbate existing grievances and the drivers of extremism and terrorism. Both Egypt and Turkey recorded substantially higher levels of terrorism following government crackdowns. ${ }^{10}$

\subsection{Terrorism}

The impact of terrorism in the modern world should never be underestimated. ${ }^{11}$ According to the Institute of Economics and Peace, the global economic cost of terrorism in 2016 was US $\$ 84$ billion, and, while this was substantial it was only a small fraction of the global economic impact of violence that was $\$ 14.3$ trillion in 2016. ${ }^{12}$ What is important to note here is that terrorism is one of the few categories of violence where costs associated with containment probably exceed its consequential costs. But, it is argued, that while the estimated economic impact of terrorism may be small it is still critical to contain it, because, terrorism has the potential to spread quickly and with significant social ramifications. ${ }^{13}$

The random use of extreme violence "to terrorize" or to strike paralyzing fear on a population, and, especially, its opinion leaders and policy makers, and, thereby, influence decision-making, in favour of the terrorist cause, research has shown to be highly ineffective as a means of realizing societal change in keeping with the terrorists' preferences. ${ }^{14}$

$10 \quad$ Ibid.

11 Hall Gardner, “Terrorism," Oxford Bibliographies, last reviewed 15 November 2016, http:// www.oxfordbibliographies.com/abstract/document/obo-9780199743292/obo9780199743292-0055.xml?rskey=mDrMWf\&result=10\&q=Counterterrorism\#firstMatch. (accessed March 24, 2019)

12 Global Terrorism Index 2017, Measuring and understanding the impact of terrorism, Institute for Economics and Peace (IEP), November 2017, IEP Report 55, p. 3. http://visionofhumanity.org/app/uploads/2017/11/Global-Terrorism-Index-2017.pdf. (accessed March 18, 2019)

13 Ibid.

14 Max Abrahms, "The Political Effectiveness of Terrorism Revisited," Comparative Political Studies, 2012, 45(3): 366-393, https://www.gwern.net/docs/terrorism/2012-abrahms.pdf. (accessed March 23, 2019); "Terrorism is not effective," created 14 April 2009, modified 7 March 2019, What's the value of x? triplebite, Gwern Branwen, https://www.gwern.net/ Terrorism-is-not-Effective. (accessed March 23, 2019) 
Refugees and other forced migrants, like everything else, has been adversely affected by $9 / 11$ and its aftermath. The preoccupation with national security and the prevention of terrorist attacks has made refugees and other forced migrants suspected security threats. All legitimate channels for entering the territory of a state have been "securitized" or "sealed," in an effort to prevent terrorists from exploiting their potential host states, for their own benefit, including, the use of the asylum systems of states to gain access and admission to their territory. ${ }^{15}$ Whether these concerns are legitimate and well-founded is another matter entirely. ${ }^{16}$

With Donald J. Trump assuming the Office of the President of the United States in January 2017, not surprisingly, ${ }^{17}$ there was a dramatic change in immigration and refugee policy. There was a suspension of immigration from what Trump called "terror-prone regions."18 Presidential Proclamation No. 9645 placed entry restrictions on the nationals of eight countries, including refugee claimants without valid travel documents: Chad, Iran, Libya, North

15 Todd Bensman, "What Migration Over European Borders can Teach about American Border Security," Centre for Immigration Studies, November 6, 2019, https://cis.org/Report/ Terrorist-Migration-Over-European-Borders. (accessed April 20, 2020) Jane McAdam, ed. Forced Migration, Human Rights and Security. Oxford: Hart Publishing, 2008.

16 Polly Toynbee, "Our borders are porous. Why can't our politicians admit the problems of immigration?" The Guardian, Opinion, Immigration and Asylum, 27 February 2010, https://www.theguardian.com/commentisfree/2010/feb/27/our-borders-are-porous. (accessed September 16, 2018); Sian Elin Dafydd, "Slavery and human trafficking aided by 'porous borders." BBC News, 16 May 2017, https://www.bbc.com/news/uk-wales-39924457. (accessed September 16, 2018)

17 Jenna Johnson, "Trump calls for a 'total and complete shutdown of Muslims entering the United States," The Washington Post, December 7, 2015, https://www.washingtonpost .com/news/post-politics/wp/2015/12/07/donald-trump-calls-for-total-and-completeshutdown-of-muslims-entering-the-united-states/?noredirect=on\&utm_term=.cdf5d46da14e. (accessed March 17, 2019); Gregory Krieg, "Trump's history of anti-Muslim rhetoric hits dangerous new low," CNN politics, November 30, 2017, https://www.cnn .com/2017/11/29/politics/donald-trump-muslim-attacks/index.html. (accessed March 17, 2019)

18 Josh Keller, Adam Pearce, Wilson Andrews, "Tracking Trumps Agenda, Step by Step," The New York Times, October 1, 2018, https://www.nytimes.com/interactive/2017/us/politics/ trump-agenda-tracker.html. (accessed March 16, 2019); Adam Liptak and Michael D. Shear, "Trump Travel Ban is Upheld by Supreme Court," The New York Times, June 26, 2018, https://www.nytimes.com/2018/o6/26/us/politics/supreme-court-trump-travel-ban .html. (accessed March 16, 2019); Presidential Proclamation No. 9645, Presidential Proclamation Enhancing Vetting Capabilities and Processes for Detecting Attempted Entry into the United States by Terrorists or Other Public-Safety Threats, September 24, 2017, Donald J. Trump, https://www.whitehouse.gov/presidential-actions/presidential-proclamation-en hancing-vetting-capabilities-processes-detecting-attempted-entry-united-states-terror ists-public-safety-threats/. (accessed March 16, 2019); Trump v. Hawaii, No. 17-965, 585 U.S. (2018), https://www.supremecourt.gov/opinions/17pdf/17-965_h315.pdf. (accessed March 17, 2019) 
Korea, Somalia, Syria, Venezuela, and Yemen. ${ }^{19}$ Following a series of court rulings, the US Supreme Court in the 2018 Trump v. Hawaii landmark ruling, in a 5 to 4 judgement with the majority opinion written by Chief Justice John Roberts, concluded that the Presidential Proclamation was valid. ${ }^{20}$

An equally contentious Trump Administration campaign promise and policy initiative has been the construction of a wall on its southern border with Mexico. ${ }^{21}$ Moreover, the Trump Administration has deployed active-duty troops to the southern border to support US Customs and Border Protection officials in "hardening the southern border."22 The impetus for the construction of the wall is, in part, "to stop illegal immigrants spreading crime and drugs." ${ }^{23}$ Nonetheless, it has been argued persuasively that, "President Trump's wall would be a mammoth expenditure that would have little impact on illegal immigration." ${ }^{24}$ In essence, the wall has become a symbol for the Trump's Administration efforts to protect the U.S. homeland from, what he has described as a foreign "invasion." ${ }^{25}$ The Trump Administration has been imposing restriction on those seeking asylum at its southern border, the Migrant Protection Protocols (MPP) or what are better known as the "Remain in Mexico."26

19 Presidential Proclamation No. 9645.

20 Trump v. Hawaii, No. 17-965, 585 U.S. (2018); Harvard Law Review, "Establishment Clause, Trump v. Hawaii, Leading Case: 138 S. Ct. 2392 (2018)” March 17, 2019, 132 Harv. L. Rev. 327, https://harvardlawreview.org/2018/11/trump-v-hawaii// (accessed March 17, 2019)

21 Amanda Holpuch, "Trump re-ups controversial Muslim ban and Mexico wall in first campaign ad," The Guardian, January 4, 2016, https://www.theguardian.com/us-news/2016/ jan/o4/donald-trump-great-again-first-campaign-ad-isis-mexico-wall-muslim-ban. (accessed March 17, 2019) Astonishingly, Trump claimed that if elected President that he would build the wall to prevent immigrants from illegally crossing into the United States from its southern border and that Mexico would pay for the wall.

22 Claire Felter and Zachery Laub, "Who Secures the U.S. Border?" Council on Foreign Relations, February 15, 2019, https://www.cfr.org/backgrounder/us-mexico-border-woes?gclid =CjwKCAjw4LfkBRBDEiwAc2DSlEkqNJCoGIJhZo5LeXX6zxZwWEjEAt9D-C2AJ7SdrGigNfSE-skWfhoCPJEQAvD_BwE. (accessed March 17, 2019)

23 David Smith, "Trump declares national emergency to build US-Mexico border wall," The Guardian, February 15, 2019, https://www.theguardian.com/us-news/2019/feb/15/nationalemergency-border-wall-trump-latest-news. (accessed March 17, 2019)

24 David Bier, “Why the Wall Won't Work," cato Institute, Commentary, this article appeared in the May 2017 issue of Reason, https://www.cato.org/publications/commentary/whywall-wont-work. (accessed March 17, 2019)

25 David Smith, "Trump declares national emergency to build US-Mexico border wall," The Guardian, February 15, 2019, https://www.theguardian.com/us-news/2019/feb/15/nationalemergency-border-wall-trump-latest-news. (accessed March 17, 2019). Wherein, Trump is quoted as saying, "We're talking about an invasion of our country, with drugs, with human traffickers, with all types of criminals and gangs."

26 Isaac Bloch and Anne Dutton, "Border Purgatory: Trump Administration's Latest Efforts to Deter Refugees," Refugees Deeply, February 22, 2019, https://www.newsdeeply.com/ 
The election of Donald Trump, as President of the United States, and his agenda of limiting the number of migrants entering the United States is due, at least in some part, to the traumatizing effects of terrorist actions within the United States but also elsewhere in the world today. Like other populist leaders, he has played on the public's insecurity and fear of terrorism following the traumatizing effects of $9 / 11 .^{27}$

\section{$2.2 \quad$ Refugees}

The other great concern of our time is the seemingly endlessly increasing numbers of refugees and other forced migrants. Indeed, the so-called, "refugee crisis," shows no signs of abetting. The number of forcibly displaced persons has been escalating for the past decade. The UNHCR has underscored that there are now over 70 million people who have been forcibly displaced in the world today. What is perhaps most astonishing is that more than two-thirds of the world's forcibly displaced people $(67 \%)$ come from only five countries: the Syrian Arab Republic; Afghanistan; South Sudan, Myanmar, and Somalia. And, sadly, about half of the world's refugees are children under the age of 18 years of age. ${ }^{28}$ These statistics underscore that the "root cause" of the vast majority of the world's refugees come from states that have been embroiled in armed conflict for years. The nature of the armed conflict is nearly entirely noninternational armed conflict that, frequently, has been internationalized. ${ }^{29}$

refugees/community/2019/02/22/border-purgatory-trump-administrations-latest-effortto-deter-refugees. (accessed March 18, 2019)

27 Molly Ball, "Donald Trump and the Politics of Fear," The Atlantic, September 2, 2016, https://www.theatlantic.com/politics/archive/2016/og/donald-trump-and-the-politicsof-fear/498116/. (accessed July 17, 2019); Julie Hirschfeld Davis, "Obama Accuses Trump of Exploiting Working-Class Fears," The New York Times, December 21, 2015, https://www .nytimes.com/2015/12/22/us/politics/president-obama-accuses-donald-trump-of-exploiting-working-class-fears.html. (accessed July 17, 2019); David Remnick, "Donald Trump's Exploitation of Orlando," The New Yorker, June 12, 2016, https://www.newyorker.com/ news/daily-comment/donald-trumps-exploitation-of-orlando. (accessed July 17, 2019); Uri Friedman, "Where America's Terrorists Actually Come From: Syrian refugees have committed zero attacks in the United States," The Atlantic, January 30, 2017. https://www. theatlantic.com/international/archive/2017/o1/trump-immigration-ban-terrorism/514361/. (accessed April 22, 2020); Tamara Khandaker, "Most Terrorists are Homegrown, Not Refugees," Vice, October 2, 2017, https://www.vice.com/en_ca/article/bjvpw8/ most-terrorists-are-homegrown-not-refugees. (accessed April 22, 2020)

28 United Nations High Commissioner for Refugees, UN HCR, Global Trends: Forced Displacement 2018. Geneva: UNHCR, 2019. https://www.unhcr.org/5do8d7ee7.pdf. (accessed June 30, 2019)

29 International Institute for Strategic Studies (IISs), Armed Conflict Survey, 2018, July 2018, Editor's Introduction, https://www.iiss.org/publications/armed-conflict-survey/2018/ armed-conflict-survey-2018/acs2018-02-introduction. (accessed March 23, 2019) 
In a fascinating paper by Barbara F. Walter, titled, "Conflict Relapse and the Sustainability of Post-Conflict Peace," she points out the "three disturbing patterns of regarding civil wars" or non-international armed conflicts and their reoccurrence ${ }^{30}$ First, she notes that civil wars have a high recidivism rate. ${ }^{31} \mathrm{Of}$ the 103 countries that experienced civil war in the period 1945-2009, only 44 did not experience a subsequent civil war. Thus, $5^{6}$ percent of the countries that had one civil war experienced another. This has been described in the literature as the "conflict trap." 32 Her second point is that "recurring civil wars have become the dominant form of armed conflict in the world today." ${ }^{33}$ This is underscored by the fact that every civil war since 2003 has been a continuation of a previous civil war. ${ }^{34}$ She states that " 90 percent of the conflicts initiated in the 21st century were in countries that had already experienced a civil war." ${ }^{35}$ Hence, she argues that "the problem of civil wars is not of preventing new conflicts from arising, but of permanently ending the ones that have already started."36 Thirdly, "civil wars are increasingly concentrated in a few regions of the world." ${ }^{37}$ She makes the point that in the first decade of the 21st century that 35 percent of all civil wars occurred in Sub-Saharan Africa. ${ }^{38}$ The observation she makes here is that "civil wars are increasingly being ghettoized in the world's poorest and weakest states." ${ }^{39}$ Walter's findings reinforce the UNHCR's statistics with respect to the fact that more than two-thirds of the world's refugees come from only five protracted, and seemingly unending, civil wars or non-international armed conflicts.

\section{Protracted Armed Conflict, Extreme Political Violence, Terrorism and Asylum}

One truism of modern warfare is that it intentionally kills people, civilian noncombatants more so than armed combatants, and destroys property on a

$30 \quad$ Barbara F. Walter, "Conflict Relapse and the Sustainability of Post-Conflict Peace," World Development Report 2011, Background Paper, September 13, 2010, World Bank, p. 1, http:// documents.worldbank.org/curated/en/128031468182669586/Conflict-relapse-and-thesustainability-of-post-conflict-peace. (accessed March 23, 2019)

31 Ibid.

32 Ibid.

33 Ibid.

34 Ibid.

35 Ibid.

36 Ibid., p. 2.

37 Ibid.

38 Ibid.

39 Ibid. 
massive scale. Another truism of modern warfare is that it produces refugees and other forced migrants on a massive scale. ${ }^{40}$ No one should be expected to have to try to live in a war zone or an armed conflict zone, where you might be subject to "cross fire" or be a victim of "collateral damage" or to have to suffer the lack of the bare necessities of life such as water, food, medicine, and, the right to earn a livelihood or a living. No one should be expected to have to try to live in a war zone or armed conflict zone and be subjected to the threat of dehydration, starvation, disease or the fear of personal insecurity that could singly or in combination prove to be fatal. In fact, modern warfare is characterized by the death of significantly more civilian non-combatants than armed combatants, with the majority of deaths being attributed to starvation and disease than deliberate targeting or collateral damage. ${ }^{41}$ Hence, it is entirely understandable that citizens would be motivated to flee the uninhabitable and the insufferable conditions of a protracted war or armed conflict.

Two points are worth emphasizing. The first is the overwhelming type of armed conflict that takes place in the world today is non-international armed conflict or intrastate conflict or civil war. The other significant point is that a number of these non-international armed conflicts have been internationalized with the participation of other states supporting one side or the other in the civil war. The "internationalization" of a civil war or internal armed conflict is what makes it a far more vicious and deadly affair that is extremely difficult to resolve and, as a consequence, tends to last much longer. ${ }^{42}$

The second point is that most of the world's terrorism occurs in situations of armed conflict or extreme political violence where, for example, a state is oppressing its own citizens. Terrorism is concentrated geographically to those regions of the world that experience protracted armed conflict and/or extreme political violence. It is important to emphasize that terrorism can take place

$40 \quad$ Mary Kaldor, New and Old Wars: Organized Violence in a Global Era. 3rd Edition. Cambridge: Polity Press, 2012.

41 Valerie Epps, "Civilian Casualties in Modern Warfare: The Death of the Collateral Damage Rule," Georgia Journal of International and Comparative Law, 2013, Vol. 41, 307-355, https://digitalcommons.law.uga.edu/cgi/viewcontent.cgi?article=1036\&context=gjicl. (accessed March 23, 2019); Neta C. Crawford, "Costs of War, Human Costs of the Post-9/11 Wars: Lethality and the Need for Transparency," Watson Institute, International and Public Affairs, Brown University, November 2018, https://watson.brown.edu/costsofwar/files/ cow/imce/papers/2018/Human\%20Costs\%2C\%20Nov\%208\%202018\%20CoW.pdf. (accessed March 23, 2019)

42 Kendra Dupuy, Scott Gates, Håvard M Nygård, Ida Rudolfsen, Siri Aas Rustad, Håvard Strand and Henrik Urdal, "Trends in Armed Conflict 1946-2016," Peace Research Institute Oslo (PRIO), 22 June 2017. ETH Zurich, Centre for Strategic Studies, http://www.css.ethz .ch/en/services/digital-library/articles/article.html/a7992888-34fc-44e6-8176-2fcb3aada995/pdf. (accessed September 15, 2018) 
both in armed conflict situations or non-armed conflict situations, that is, both in times of war and in peace. The essential aspect is that organized extreme violence is the fundamental characteristic under circumstances of either protracted armed conflict or extreme political violence such as under a totalitarian regime. ${ }^{43}$

The pertinent point here with respect to forced displacement is that terrorism can serve as an accelerator of mass forced displacement in situations of armed conflict or political violence. The fear that terrorism imposes on civilians and the public at large in situations of armed conflict and extreme political violence can trigger and result in widespread mass forced displacement. In short, terrorism accelerates mass forced displacement in a war setting or situation of extreme political violence. ${ }^{4}$

If war and armed conflict are synonymous with the mass production of refugees, then, terrorism is its catalyst. Consequently, these four terms are intimately related: protracted armed conflict; extreme political violence; terrorism; and, forced displacement. From this, it is obvious that to resolve the so-called "refugee crisis" in the world today it is necessary to address the problem of terrorism within the context of protracted armed conflict and/or extreme political violence.

\section{$4 \quad$ Analyzing the Relationship between Terrorism and Asylum}

The purpose of this edited volume is to explore in detail the relationship between terrorism and asylum in all its interrelated and variable aspects, variants, and permutations. It considers the role that terrorism plays as a driver in forced displacement within the context of protracted armed conflict and extreme political violence. It also considers the role that terrorism plays in the refugee status determination process, both as a basis for a well-founded fear of persecution within the context of a state that is not willing or able to

43 START, National Consortium for the Study of Terrorism and Responses to Terrorism, Background Report, Global Terrorism 2017, University of Maryland, August 2018, https://www .start.umd.edu/pubs/START_GTD_Overview2017_July2018.pdf. (accessed September 15, 2018)

44 Phil Orchard, "Making States Accountable for Deliberate Forced Displacement," World Refugee Council Research Paper No. 17 -- June 25, 2019, https://www.cigionline.org/publications/making-states-accountable-deliberate-forced-displacement. (accessed April 20, 2020) James C. Simeon, "Enhancing Refugee Protection Through the Criminalization of 'Mass Forced Displacement." RLI Blog on Refugee Law and Forced Migration, August 2, 2018, https://rli.blogs.sas.ac.uk/2018/o8/o2/enhancing-refugee-protection-through-thecriminalization-of-mass-forced-displacement/. (accessed September 15, 2018) 
provide the refugee applicant adequate state protection from the alleged perpetrators of terrorism and the alleged persecutors. It will also consider the exclusion from refugee protection of all those who have been involved in terrorist activities. It will also consider how terrorism has been driving the public policy agenda regarding refugees and other forced migrants in a number of different jurisdictions. Politicians have been using the fear generated by the risk of terrorist attacks to further their public policy agenda to limit and to restrict refugees' access to refugee protection within their respective countries. The edited collection concludes by identifying the major issues and concerns related to refugees and terrorism and how these might be addressed in the broader public interest while, at the same time, protecting and advancing the human rights and dignity of everyone.

This edited volume on "Terrorism and Asylum" brings together a number of senior legal scholars, researchers and academics to provide their original work on a very important topic that has pre-occupied States, in a very serious way, for close to the last two decades, if not more. The edited volume fills a very important existing gap in the literature on public international law, dealing with both international criminal law and, specifically, with the "crime of terrorism," and international refugee law, and, in particular, the exclusion from asylum under Article $\mathrm{iF}$ for being involved in terrorism or terrorist activities. This edited volume provides an innovative, detailed, and thorough legal analysis, from a number of different levels and perspectives, of "terrorism and asylum" in international, transnational, and national law, with the aim of providing new insights, analyses, findings, and recommendations for how to address these modern challenges confronting the world community today, within and across States - as well as regionally and internationally, in the seemingly ever escalating 'wicked public policy problems' of terrorism, ${ }^{45}$ and, the ongoing, and seemingly ever rising, unprecedented "refugee crisis." 46

45 Brian Head, “Understanding 'Wicked' Policy Problems," Policy Options, January 9, 2018, https://policyoptions.irpp.org/magazines/january-2018/understanding-wicked-policyproblems/. (accessed April 20, 2020). Fact Sheet, For up-to-date knowledge relating to healthy public policy, "Wicked Problems and Public Policy," June 2013, National Collaborating Centre for Healthy Public Policy, Institut National de sante publique, Quebec, https://www.inspq.qc.ca/pdf/publications/1841_Wicked_Problems_Policy.pdf. (accessed September 16, 2018)

46 Centre for International Governance Innovation, Transforming the Global Refugee System, https://www.cigionline.org/interactives/2017annualreport/index.html?gclid=CjoKCQjw vfcBRDJARIsAJafEnFMjHGBlZhı2ppghrmgchjMjKgdqh9iIraSUpLszbPhfKSYcoMxlLgaAmVnEALw_wcB\#/?slide=11. (accessed September 16, 2018); World Refugee Council, https://www.worldrefugeecouncil.org/?source=ar2017. (accessed September 16, 2018). Wherein it states, "Bold and creative thinking is required to address the global refugee crisis." 
What follows is further background and contextual information for this edited collection and it continues with an outline and explanation of the relationship and interdependence, among and between, these four key concepts: protracted armed conflict, extreme political violence, terrorism and forced displacement. It further makes reference to the concept of "securitization" and how this has impacted those seeking asylum with a well-founded fear of persecution. It then goes on to indicate how this edited collection fits into the existing literature on terrorism and on asylum. Moreover, it presents the rationale for why this volume is necessary, how it is structured, who this book is intended for, and, it finishes with some final thoughts and justifications for the volume, in light of the fact that it came out of a "Terrorism and Asylum" Workshop that was sponsored and held at the Refugee Law Initiative (RLI), School of Advanced Study, University of London, in December 2017 and has resulted in a number of important contributions to this critical topic in international refugee, criminal, and humanitarian law and to the field of refugees and forced migration studies in general.

How This Edited Volume Fits into the Existing Literature on Terrorism and Asylum

Although there is an extensive literature on terrorism and on asylum, the literature examining 'terrorism and asylum' is scant. I have included some of the following sources available in the literature that demonstrates this basic point. Some of these works cover the topic of "terrorism and asylum" but often times not directly. There are a number of exceptions that are worth noting. Some of the notable exceptions, include: Sarah Singer's book, Terrorism and Exclusion from Refugee Status in the UK:Asylum Seekers Suspected of Serious Criminality; ${ }^{47}$ Alex P. Schmid, "Links Between Terrorism and Migration: An Exploration"; ${ }^{48}$ Alex Nowrasteh, "Terrorism and Immigration: A Risk Analysis"; ${ }^{49}$ Swetha Sridharan, "Material Support to Terrorism - Consequences for Refugees and Asylum Seekers in the United States"; 50 Won Kidane, "The Terrorism Bar to Asylum

47 Sarah Singer, Terrorism and Exclusion from Refugee Status in the UK: Asylum Seekers Suspected of Serious Criminality. Leiden, The Netherlands: Koninklijke Brill, 2015.

48 Alex P. Schmid, "Links Between Terrorism and Migration: An Exploration," International Centre for Counter-Terrorism, The Hague, ICCт Research Paper, May 2016, https://www .icct.nl/wp-content/uploads/2016/05/Alex-P.-Schmid-Links-between-Terrorism-andMigration-1.pdf. (accessed September 13, 2018)

49 Alex Nowrasteh, Terrorism and Immigration: A Risk Analysis. CATo Institute, September 13, 2016. https://www.cato.org/publications/policy-analysis/terrorism-immigration-riskanalysis. (accessed September 13, 2018)

5o Swetha Sridharan, "Material Support to Terrorism - Consequences for Refugees and Asylum Seekers in the United States," Migration Information Source, Migration Policy 
in Australia, Canada, the United Kingdom, and the United States: Transporting Best Practices"; 51 and, Maria Paz, "Asylum and Terrorism: The Death of Human Rights Law?"52 among some others. And, of course, the extensive work that has been done on this subject by Ben Saul, that includes: "Exclusion of Suspected Terrorists from Asylum: Trends in International and European Refugee Law," Research Handbook on International Law and Terrorism; Defining Terrorism in International Law. ${ }^{53}$

However, this edited collection is unique in that it covers the topic of "terrorism and asylum" directly and from the perspective of a number of essential aspects: normative; international and transnational law; and, national law and practice. It is the only book of its kind that features the work of a number of highly established international refugee law scholars as well as a number of promising new legal scholars in the early stages of their careers. Accordingly, this volume seeks to make an important contribution to the literature on this critical subject matter that explores the complex, complicated and convoluted relationship between "Terrorism and Asylum." ${ }^{4}$

This edited collection, thus, aims to fill an important gap in the existing literature on the connections between two crucial concepts in the world today, terrorism and asylum. The volume is comprised of 11 original chapters, and with an introductory and a concluding chapter. The chapters are arrayed in

Institute, January 30, 2008, https://www.migrationpolicy.org/article/material-supportterrorism-\%E2\%80\%94-consequences-refugees-and-asylum-seekers-united-states. (accessed September 13, 2018)

51 Won Kidane, "The Terrorism Bar to Asylum in Australia, Canada, the United Kingdom, and the United States: Transporting Best Practices," Fordham International Law Journal, 2009-2010, Vol. 33, pp. 300-371. https://digitalcommons.law.seattleu.edu/cgi/viewcontent.cgi?article $=1068 \&$ context=faculty. $($ accessed September 15,2018 )

52 Maria Paz, "Asylum and Terrorism: The Death of Human Rights Law?" Iowa Law Review Online, 102, 41 (2016), https://ilr.law.uiowa.edu/online/volume-102/asylum-and-terrorismthe-death-of-human-rights-law/. (accessed September 15, 2018)

53 Ben Saul, "Exclusion of Suspected Terrorists from Asylum: Trends in International and European Refugee Law," IIIs Discussion Paper No. 26, June 2005. https://papers.ssrn.com/ sol3/papers.cfm?abstract_id=735265. (accessed September 15, 2018); Ben Saul, ed. Research Handbook on International Law and Terrorism. Cheltenham: Edward Elgar Publishing Inc., 2014; Ben Saul, Defining Terrorism in International Law. Oxford: Oxford University Press, 2006.

54 Juan Carlos Antunez, "Refugees and Terrorism: The Real Threat," GESI, International Securities Studies Group, Universidad De Granada, October 21, 2019, https://www.seguridadinternacional.es/?q=en/content/refugees-and-terrorism-real-threat. (accessed April 22, 2020) James C. Simeon, "Exposing Terrorism False Association with Asylum," Canadian Association for Refugees and Forced Migration Studies (CARFMS) Newsletter, Winter 2018, Issue 9, pp. 13-19. http://carfms.org/wp-content/uploads/2018/o1/CARFMS-newsletterwinter-2018.pdf. (accessed September 15, 2018) 
three parts: (1) the normative constructions of exclusion from asylum for terrorist activities; (2) international, transnational, and national perspectives on the crime of terrorism; and, (3) the national dimensions and dynamics of terrorism and exclusion from asylum. Each of the parts of the collection builds upon the other to allow the reader to develop their knowledge and understanding of the subject matter in logical and discreet portions. To acquire a fuller and a deeper understanding of the subject matter it is best to read the chapters sequentially. Nonetheless, each of the chapters can stand on their own and can allow the reader to gain a deeper appreciation of the subject matter and the contents that are addressed in each of the individual contributions.

The logic of the three parts of the collection should be self-evident. Starting from the normative basis of the concepts of "terrorism" and "asylum," the collection then moves on, in the second part, to an examination and consideration of the international, transnational and national crime of terrorism and its relation to asylum. The third part deals with the national dimensions and dynamics of terrorism and exclusion from asylum. Organized on this basis, all three levels of legal analysis are covered: international, transnational, and national. The structure of the text helps to ensure that the edited collection provides a thorough and comprehensive coverage of the subject matter. It also provides a familiar framework for providing a detailed and in depth analysis of a highly complex and complicated phenomenon: the interplay between terrorism and asylum and its ever shifting contours and dynamics, within the international, transnational and national contexts.

One of the important and innovative contributions of this edited volume is the manner that it approaches the topic of "terrorism and asylum." There is nothing in the literature to date that takes this multi-layered legal analysis on this subject matter. In this way, it is breaking new ground and will, therefore, make, hopefully, a significant contribution to this area of research, study, and analysis. In addition, it will hopefully also generate new insights, findings, and policy relevant recommendations for how to address these critical areas of international, transnational and national law and to public policy and administration. It should, equally, it is hoped, make an important contribution to public international law and, hopefully, international refugee and criminal law.

An edited volume of this nature will be of interest to a broad cross section of a segment of the public and, especially, anyone who may have an interest in international law, terrorism, refugees, and forced migration issues and concerns. Further, a volume of this nature on a topic of such vital public importance as this is long overdue. 
To reiterate, the edited volume covers two of the most significant legal and public policy issues and concerns of our time. Its policy relevance should be obvious, and, its impact over time will likely prove to be important and far reaching.

As noted, the idea for this edited volume came out of the "Terrorism and Asylum" Workshop that was held at the Refugee Law Initiative, School of Advanced Study, University of London, London, UK, on December 8, 2017. ${ }^{55}$ The Workshop was a success and produced a Report ${ }^{56}$ and a Special Issue of the RLI Working Paper Series of some of the papers that were presented at the Workshop. ${ }^{57}$ Only five of the contributors to this edited collection were part of the RLI Working Papers Series publication and their chapter contributions have all been updated and revised extensively and differ quite substantially from their published RLI Working Papers. All of the other contributions, six new ones, are original contributions that also include, this introductory chapter and a concluding chapter that are all entirely new contributions for this volume.

It is important and worth emphasizing here that the "Terrorism and Asylum" Workshop was also a success in providing researchers, practitioners and graduate students with an opportunity to present their work on this topic, obtain expert feedback, and continue working on their papers for publication. This edited volume is a continuation of this previous work, in part, but, with the addition of a number of other outstanding legal scholars, researchers and academics in the field of international and national law who have also done work on terrorism and asylum.

In short, this edited collection should prove valuable to those who are working directly in the field of refugee law writ large. The work being done on this subject matter is of great interest and of need to everyone who is interested and concerned with these two overriding issues and concerns. We fully anticipate, and very much hope, that an edited volume of this nature will be of great interest and will make an important contribution to the literature in this

55 “RLI, 'Terrorism and Asylum' Workshop: Report Published," Refugee Law Initiative, School of Advanced Study, University of London, January 23, 2018. https://rli.sas.ac.uk/about-us/ news/rli-terrorism-and-asylum-workshop-report-published. (accessed September 15, 2018)

56 James C. Simeon, “Terrorism and Asylum' Workshop Report," Refugee Law Initiative, School of Advanced Study, University of London, January 23, 2018, https://rli.sas.ac.uk/ sites/default/files/files/Terrorism\%20and\%2oAsylum\%2oWorkshop\%2oReport_RLI.pdf. (accessed September 15, 2018)

57 Refugee Law Initiative, Terrorism and Asylum (RLI Working Paper Series Mini-Volume), January 2019, https://sas-space.sas.ac.uk/9204/. (accessed March 23, 2019) 
subject area, but, also to the knowledge and understanding that will be generated on the crucial subject of "Terrorism and Asylum."

\subsection{The Chapter Contributions}

\subsubsection{Part One}

Part one of this edited collection covers the normative constructions of asylum and exclusion from asylum for terrorist activities and includes four chapters. The first of these is by Patricia Tuitt who addresses the subject, "The construction of a terrorist under Article 1 of the Convention relating to the Status of Refugees"; this is followed by Selina March, who's chapter is entitled, "Manufacturing Fear: Examining the Social Components of Anti-Immigration Policies within Counter-Terrorism Discourse." The third by John R. Campbell, takes an anthropological approach to understanding the law of terrorism and the "secret trials" of terrorists. His chapter is titled, "Guilty by Association: Contrasting Views on the Fairness of the "Secret Trials" of "Terrorists." And, Christopher McDowell presents his chapter on "Forced Migration, Diaspora Politics and Extremism: Conceptual, Policy and Operational Implications with a Focus on the United Kingdom." Together they examine the normative constructions of asylum and exclusion from asylum for terrorist activities and so much more.

Patricia Tuitt's philosophy of law approach challenges the very basis of the ${ }_{1951}$ Convention relating to the Status of Refugees in her broad sweeping examination of the very legitimacy of law itself that is based on the foundations of the exercise of violence. Drawing on the works of Walter Benjamin, she articulates that the essence of violence, from a historical philosophical reading, is its dualist distinction between sanctioned versus unsanctioned violence. Tuitt argues that "it is violence that preserves the law against the forces that would threaten its stability." Likewise, she incorporates the work of Nisha Kapoor who provides the insight that the justification for the use of excessive levels of state power as both necessary and legitimate in the policing of the "terrorist suspect." This begs the question, then, of how the nature and degree of state force can be legally sanctioned within the parameters of a humanitarian framework. The ready reply here is that there are certain acts of violence - the indiscriminate and random killing of innocent civilians - that are deemed to be simply "evil." But, Tuitt also recognizes that within the ${ }_{1951}$ Refugee Convention is the legal right that undermines, in a way, the state monopoly of violence but that this is curtailed immediately by the construction of the "refugee terrorist" who poses a threat to the state. The very foundation of the state is premised on its ability to maintain its territorial integrity, the security of its population, and the exercise of its legitimate authority. Volker Turk, among others, has argued that the framework of international refugee law is based on the security of the refugee and the security of the state. Tuitt questions whether states have, 
indeed, achieved the right balance between "legitimate self-preservation and humanitarianism." Nonetheless, Tuitt emphasizes Article 1F's central place in the 1951 Refugee Convention.

With respect to the UK, Tuitt, reviews the Special Immigration Appeals Commission (SIAC) and its statutory framework that allows for the appellant not to be given all of the particulars of their reasons for their decision and any appeals against their decisions must be filed within ten days for those still in the UK and 28 days if outside the UK. One of the great criticisms of the SIAC process, Tuitt emphasizes, is that it can hold hearings in private and in the absence of either the appellant or his or her legal representative. The critics of the SIAC process have noted that it breaches the principles of fundamental justice by holding secret trials, the appellant and their lawyer have restricted access to information, and do not have the right to know the case against them, despite the fact that there is a special counsel assigned to the case who can review the evidence against the appellant, but, once the trial starts can no longer have any contact with the appellant or their counsel. Critics such as Nisha Kapoor argue that the standard of proof in terrorism cases is unacceptably low. Tuitt concludes her chapter by noting that the treatment of terror suspects in the UK legal system, especially those that are made in secret 'closed court', has the effect of a denial of justice.

Selina March's chapter seeks to untangle the complex intertwined relationship of terrorism and asylum. March focuses on the social component of the terrorism and asylum nexus. She argues that a securitization narrative, within a counter-terrorism discourse, allows politicians to dampen any sympathetic reactions to the plight of refugees while rationalizing the restrictive response to national security concerns. In short, she contends that politicians' resort to immigration as a "hot button" issue to gather political support and votes when they pit national security concerns against the safety of asylum seekers. The chapter examines the rise of anti-immigrant sentiment and policy in the United States with the surprise election of Donald Trump as US President. Using critical race theory, March asserts that racism is deeply engrained in US society and that law is not neutral but, rather, reinforces racial hierarchies. In this regard, the Trump Presidency has been characterized by "fearmongering tactics and policy positions" that have advanced anti-immigrant policies through the guise of "making America great again." The advancement of a narrative that characterizes immigrants and refugees as a national security threat, March argues, further codifies nativist sentiment. What is evident is that Trump is the figurehead of the current US anti-immigrant policies and what is critical is that a number of social components are driving these policies consisting of existing biases, insecurities and fears and increased social and political polarisation, among others, that can be classified as the worldview of 
the American populace. March identifies two key strategies to legitimize this worldview. The first stratagem is to group refugees with other migrants and, the second, is to normalize a factual, but, unwarranted link between refugees and Muslim-majority countries and terrorism. The 'fear of terrorism' is employed to influence the worldview of wide sections of the American public in order to manufacture the 'cultural racism' necessary to push through policies for banning or significantly curtailing the number of refugees resettling in the United States. In addition, March points out, that the rhetoric surrounding the 'zero-tolerance policy' and the 'migrant caravan' is riddled with criminalization and dehumanization narratives that are intended to distance the general public from the asylum seekers. The use of labels such as "aliens" and "illegals" furthers the objectification and "othering" of asylum seekers, a process that is consistent with fostering 'cultural racism'. The current anti-immigrant and nativist rhetoric goes well beyond the individual racism of Trump and his supporters, March argues, and it is essential to be able to understand the deeper cultural and institutional narratives to get a full appreciation of the extent of the problem and the challenge of addressing it. Consequently, a critical assessment of current immigration and refugee policies is absolutely necessary in order to understand and untangle convoluted negative and deliberately exploited inter-relationships between terrorism and asylum, if we ever hope to address properly these two central concerns of our time.

John R. Campbell examines the "secret trials" of terrorists by contrasting the normative judgements of the law with the anthropological requirements of situating the cases in the wider social context of society to understand the complex legal processes and the roles played by the state, the courts, judges, lawyers, and defendants. Campbell argues that terrorist attacks since $9 / 11$ have given legislators the authority to reshape, fundamentally, the quality of justice and the work of the law in Europe and North America. Campbell notes that this is especially evident in the immigration policy field where strategic preoccupations about national security and terrorism have been used to rewrite the law, pass new legislation, and reinforce the discretionary power of the political executive in ways that would not have been possible prior to 9/11. The argument is made that "counter-terrorism" measures have shifted from investigation, criminalization and the proscription of individuals and organizations to preemptive, anticipatory, and preventative strategies. This chapter focuses specifically on the "Closed Material Proceedings" (CMP) or "secret trials." These types of trials have serious implications for the defendant's right to have a fair trial; including: (a) the right to be tried by an independent and impartial tribunal; (b) the right to have one's case defended on the basis of established facts and the law; and, (c) the right to know the case you have to meet and the 
right to respond to that case in an open court. "Secret trials," Campbell points out, need to be understood as uneven contests between the defendant and the state whose outcomes are influenced by many inter-related factors such as an ever changing legislative agenda; lobbying in Parliament and the House of Lords; efforts by the Home Office to create primary legislation, and so on. What is thoroughly examined here is the case of $\mathrm{O}_{2}$, a person who was charged and tried under the CMP. Campbell served as an "expert witness" in his trial. Such trials are conducted by the Special Immigration Appeals Commission (SIAC) and the appellants are represented by a Special Advocate (SA), a lawyer who is vetted by the Security Service, and who gets access to secret evidence, that only the judges and SAs are privy to. The role of the SA is to protect the human rights of the accused, but, they are barred from communicating with the accused or their counsel after they have been given access to the secret evidence. Campbell reviews the testimony of the appellant in this "secret trial" at SIAC, where he presented two "expert witness" reports, and finds the judgements in this case, of both the presiding Justice at SIAC and at the Court of Appeal, to be wanting. Obtaining a conviction under the Prevention of Terrorism Act based on a mere "reasonable suspicion" of being involved in terrorist related acts is hardly a high standard of proof. Campbell concludes by noting that "secret trials," that rely on the use of SA, undermine some of the most fundamental principles of procedural fairness and, consequently, are unlike to produce just outcomes.

Christopher McDowell's chapter focuses on the displacement and security threat nexus and the response to conflict induced displacement and refugee resettlement. McDowell's chapter is concerned with the aggressive recruitment and the radicalization of vulnerable persons, whether they are asylum seekers or nationals. He argues that extremist networks are exploiting the spaces created by the failures of refugee protection and integration in host societies. Inevitably, inherent in the internationalization of contemporary conflict are at least four interrelated elements: large scale population displacement, dispersal, encampment, and the refugee journey; the process and experience of settlement and integration in the country of asylum; diaspora politics that links the movement and settlement; and, the growing involvement of organized criminality in asylum migration. McDowell's chapter is based on the Centre for Research and Evidence on Security Threats (CREST) funded research conducted in the United Kingdom, Europe, and Canada that examined diaspora refugee politics and on McDowell's commissioned research on Syrian resettlement in the UK. The CREST project examined the internationalization of the Sri Lankan civil war, between 1983 to 2009 , and Tamil diaspora politics and the strategies of the Liberation Tigers of Tamil Eelam (LTTE) to further their political and military objectives through the mobilization of Tamil asylum seekers and refugees in 
Western States. McDowell argues that the LTTE provided a model for international Jihadists and Salafi political activists among Europe-bound migrants and refugees fleeing the protracted armed conflicts in the Middle East. Drawing on the diaspora, conflict and refugee studies literature and the extremism and radicalization literature, McDowell points out that diasporic associations and their elites play a central role in the mobilization of their communities by seizing specific events and framing the issues and defining grievances and claims to legitimate political action. The prevalence of terrorist attacks in Europe since 2016 has raised questions about what may be specific with respect to refugee diaspora politics, asylum seeking, and integration that increase the risk to radicalization. With respect to the triggers of radicalization among migrants and refugees, McDowell identifies the following: identity crises; social alienation; discrimination and/or social exclusion; racism; and, poverty. His own research on the subject has demonstrated how the direct engagement of extremist networks in displacement and the onward refugee journey creates opportunities to keep the conflict 'alive' with overseas populations. McDowell argues that the exploitation of asylum migration and settlement allows for the building of networks and dependent relationships with the displaced, that may be mobilized at some later date for either a benign or maligned purpose. In the case of the LTTE, it had a highly sophisticated transnational network that coordinated the flow of information and propaganda and oversaw the collection of "donations" that were vital to the struggle for an independent Tamil homeland. In addition, the LTTE used the asylum system of States to pension off their fighters who could no longer serve on the front lines. The LTTE provided their diaspora communities with the kind of social support they needed to settle abroad, but in the process became dependent on them and, especially, among those who still had family members living in Sri Lanka. McDowell also points to evidence that shows that Jihadists and Safalist extremist networks are applying the LTTE's strategy for harnessing its diaspora into serving its needs. There is evidence that these extremist groups are recruiting among refugees in Lebanon, Jordan and Turkey. McDowell's own research among the Syrian refugees in the UK found that, among those on the move, the highest risk group was young men, 16-30 years old. What the data demonstrated was that engagement in extremist politics is more likely when there are 'opportunities to engage'. It was further discerned that among those who were convicted of terrorist offenses were people who migrated to the UK with their families as children or people who migrated alone as teenagers or young adults. The typical radicalized profile appears to be young men who are disaffected with the state and their host communities. 
The chapter also considers the 2018 UK Parliament's Intelligence and Security Committee of Parliament's Report and the 2017 Anderson Operational Improvement Review and the 2018 UK counter terrorism strategy, CONTEST. McDowell focuses on the weaknesses of CONTEST by noting that it fails to connect the national to the international dimensions of terrorism and the commonality of the "internationalization of conflict." This is the central weakness of current counter terrorism strategies and practices in the UK and, most likely, on a transnational basis as well.

\subsubsection{Part Two}

Part two of the edited collection covers the topic of "International, Transnational, and National Perspectives on the Crime of Terrorism and Asylum." It includes three chapters by the following authors and their titles:Joseph Ripkof covers the subject of "Complicity in Exclusion for Terrorist Crimes" while, Peter Billings and Rebecca Ananian-Welsh deal with the subject of "Counter-Terrorism and the Exclusion of Refugees and Refugee-Citizens from Australia"; and, James C. Simeon, the editor of this volume, who covers the subject of "Prosecution and Exclusion for Terrorism in International and National Law."

Joseph Rikhof's contribution considers the parameters of complicity in exclusion from refugee protection for terrorist crimes. Rikhof begins by stating that even though it is possible to exclude those who are involved in terrorist activities under all the subsections of Article $1 \mathrm{~F}$, in practice states have relied on Articles $\mathrm{i}(\mathrm{b})$ and $\mathrm{i}(\mathrm{c})$ to do so. While the vast majority of those who are excluded for their complicity in serious international crimes come under Article $1 \mathrm{~F}(\mathrm{a})$, the situation for exclusion under Articles $\mathrm{1} F(\mathrm{~b})$ and $\mathrm{1} F(\mathrm{c})$ cover a broad spectrum from personal participation to complicity and, consequently, are not as clear cut. Rikhof examines the jurisprudence with respect to Article ${ }_{1} \mathrm{~F}(\mathrm{a}),(\mathrm{b})$, and (c) to discern the methodology that was used to determine the appropriate test for complicity within each subsection of Article $1 \mathrm{~F}$. Keeping in mind, however, that Article $1 \mathrm{~F}(\mathrm{a})$ differs as it imports International Criminal Law (ICL) within its provisions. The status of terrorism in international law, Rikhof underscores, is the subject of some debate. It is part of Transnational Criminal Law (TCL), as found in various treaties dealing with the suppression of terrorism, and since several states have used universal jurisdiction for the prosecution of terrorism makes it part of International Criminal Law (ICL) as well.

Turning to the 1937 Convention for the Prevention and the Punishment of Terrorism that lists an array of extended liability concepts that include:

1) Conspiracy to commit any such act;

2) Any incitement to any such act, if successful; 
3) Direct public incitement to any acts mentioned under heads (1), (2) or (3) of Article 2, whether the incitement be successful or not;

4) Wilful participation in any such act;

5) Assistance, knowingly given, towards the commission of any such act.

Rikhof compiles a list of all the forms of complicity found in the post-World War II terrorism treaties, eight in total, that include the following:

- attempt

- organizes

- directs

- participates as an accomplice

- assisting after the fact

- conspiracy

- common purpose

- threat.

He also notes that the 1998 Rome Statute of the International Criminal Court includes the following types of involvement:

- ordering,

- soliciting,

- inducing,

- aiding and abetting,

- common purpose,

- incitement,

- attempt,

- command/superior responsibility.

Rikhof concentrates on ten Western liberal democracies: Australia; Belgium; Canada; France; Germany; The Netherlands; New Zealand; Sweden; UK; and USA, that have contributed the most on exclusion. In terms of methodology, he examines the terrorism legislation with respected to extended liability in these ten countries. These countries seem to apply similar conceptual notions of extended liability with respect to personal liability. However, the precise parameters of liability vary from country to country. For half of these countries, Australia, Canada, New Zealand, UK, and the US, use more inchoate liability such as attempt, conspiracy, and incitement. In the common law jurisdictions, common purpose and common intention are used to delineate forms of group liability. Rikhof considers the Criminal Code provisions of these ten countries to analyze comparatively the different forms of extended liability. He concludes that there is wide variation amongst these ten countries of the different forms of extended liability with 25 forms of assistance to terrorist offences or individuals involved in such offences. And, there are 16 forms of assistance to terrorist organizations, groups or associations. Two questions are raised among 
the 41 forms of extended liability for terrorist activities: Are the 41 forms of extended liability unique descriptions or are they further clarifications of the general forms of complicity that are set out in criminal law?; and, If these are unique forms of liability do they add to the regular forms of liability and are they already within the parameters and overarching tests of JS (Sri Lanka) and Ezokola? With respect to the first question, Rikhof states, that several forms of extended liability are related to aiding and abetting and in this regard recommends considering the Charles Taylor case that was before the Sierra Leone Special Court. Rikhof concludes by stating, the "number of types of extended liability in national criminal legislation now go beyond the extended liability in refugee law in $\mathrm{iF}(\mathrm{a})$ with the recent contractions in the area of membership." He argues that for Articles $1 \mathrm{~F}(\mathrm{a})$ and $\mathrm{i}(\mathrm{b})$ all forms of extended liability should apply to both of these provisions of the exclusion clauses. What follows then is that International Criminal Law can be imported into Article ${ }_{1} \mathrm{~F}(\mathrm{~b})$. Transnational Criminal Law could also be applied to Article ${ }_{1} \mathrm{~F}(\mathrm{~b})$. Equally, it is argued, these extended forms of liability would also be applicable to Article $1 \mathrm{~F}(\mathrm{c})$. Hence, International Criminal Law is very much part of all of the subsections of Article $1 \mathrm{~F}$ and not simply $1 \mathrm{~F}(\mathrm{a})$.

Peter Billings and Rebecca Ananian-Welsh note that the securitization of migration, and particularly those that are identified as risky, epitomizes the "growing culture of exclusion" from asylum. Focusing on Australia, they point out that their "crimmigration" laws have essentially outlawed seeking asylum by boat. The Australian Government has also introduced national security grounds for revocation of Australian citizenship to dual nationals, so that they can be rendered alien and subjected to the Australian securitized migration system. Billings and Ananian-Welsh point out that the Howard Government in Australia, from October 2001 to November 2003, used military interdiction at sea with regional offshore processing and temporary protection visas as a response to asylum seekers that became known as the "Pacific Solution." They note that, "The Howard Government justified these policies by constructing asylum seekers as potential terrorists, which had significant political impact in the wake of the notorious MV Tampa affair and 9/11." In 2013, the Australian government returned to its practice of offshore processing, the detention of asylum seekers, and maritime interdiction, through a militaryled, "Operation Sovereign Borders." These policies are intended to deter and to disrupt irregular migration at sea for the purpose of preventing people smuggling, a serious transnational crime, and promoting human security by preventing hazardous journeys on unseaworthy vessels, and restoring integrity to the immigration system and, thus, facilitating an orderly and controlled humanitarian intake. 
Billings and Ananian-Welsh indicate that the exclusion provisions under Article $1 \mathrm{~F}$ of the 1951 Refugee Convention are of secondary and minor importance in comparison to the Australian Migration Act's call for exclusion for refugee protection: (1) on national security grounds; (2) because they are a danger to the community; and, (3) by failing public interest criteria. And, since 2014, importantly, the statutory power of removal is no longer conditional on the legal requirement to consider the fundamental principle of non-refoulement before administrative action is taken. Consequently, Billings and Ananian-Welsh state that the Australian Government purports to meet its non-refoulement treaty obligations through policy and practice and not the rule of law. The 1979 Australian Security Intelligence Organization Act (ASIO) allows for security officials to determine whether the person is a security threat, and, if they do, then, the person is removable and cannot be determined in need of refugee protection and may be held in detention. Indefinite detention is constitutionally permissible in Australia. This could result in those who are perceived to be a national security threat with protracted detention if they are not removable.

The Australian 1995 Criminal Code defines a 'terrorist act' as "an action or threat necessarily undertaken with the intention of advancing a political, or religious, or ideological cause, and either coercing or influencing by intimidation a government, or intimidating the public or a section of the public."58 Defining what constitutes a political intent is a matter of some contention, Billings and Ananian-Welsh, outline that "a political motivation must be more than a significant factor, it must be the primary motivation."

Article $\mathrm{iF}$ is rarely invoked in Australia for at least two reasons: there are many alternative grounds for excluding someone such as an adverse security assessment and the character test; and, Article $\mathrm{iF}$ entails greater transparency, procedural justice and independent review rights attendant to these decisions compared to the adverse security assessments and adverse character test. The broad-based discretionary powers of the Minister to determine under "reasonable suspicion" of mere membership of a relevant group. Membership in a terrorist organization is subject to a ten-year imprisonment in Australia. Terrorist organisation offences further extend, to directing, recruiting, training, funding and supporting these groups, with these offences attracting up to 25 years imprisonment if the person knows the group is a terrorist organisation, and up to 15 years if the person is reckless as to this fact.

$5^{8} \quad$ This definition is similar to what is found in the United Kingdom and Canada. See James C. Simeon, "The Evolving Common Law Jurisprudence Combatting the Threat of Terrorism in the United Kingdom, United States, and Canada." Laws, 2019, 8, 5. https://www .mdpi.com/2075-471X/8/1/5. (accessed April 19, 2019) 
The revoking of the Australian citizenship of dual nationals is also a major concern as it may leave the person stateless, contrary to international law, and/or leave them in "legal limbo" with the potential risk of refoulement and possibly indefinite administrative detention. Dual nationals who are members of or are instructed by, or are cooperating with, a listed terrorist organization have satisfied the "renunciation by conduct" ground for loss of citizenship. The revoking of Australian citizenship of dual nationals is automatic when a person serves in the armed forces of a country at war with Australia or serves or fights for a listed terrorist organization. The third way in which a dual national can lose their Australian citizenship is by being convicted of one or more terrorist offences or foreign incursion offences and is sentenced to six or more years of imprisonment. Billings and Ananian-Welsh conclude by observing that Australian Governments have repeatedly redefined and limited their responsibilities of providing asylum seekers protection under municipal law and have concentrated instead on broad and effectively non-reviewable decisionmaking power in security officials and politicians and, thereby, the appropriate application of the rule of law. The purported connection between asylum seekers and refugees with terrorism has been the justification for the securitization of immigration and asylum laws. While, at the same time, this approach risks alienating minority groups and those seeking protection, coupled with the failure to respect human rights and the rule of law, it lowers Australia's domestic and global status and, arguably, risks making individuals more vulnerable to radicalization and recruitment. Billings and Ananian-Welsh conclude that the Australian approach to counterterrorism, as it impacts immigration, is "secretive and largely unreviewable" with "the focus on securitization and exclusion."

James C. Simeon examines the prosecution of the "crime of terrorism" in international criminal law, based on three infamous cases at the International Criminal Tribunal of the Former Yugoslavia (ICTY), and exclusion from asylum of those who are responsible for terrorism, based on three Supreme Court judgements in Canada, United States, and the United Kingdom. Clearly, international criminal law and international humanitarian law have prohibited terrorism in situations of international and non-international armed conflict. Despite the fact there is a clear prohibition of terrorism in international humanitarian law, both in terms of customary international law and treaty law, but, no universally accepted definition of terrorism or, in fact, a comprehensive convention on terrorism, and, because states have failed to agree on a common definition of what constitutes terrorism, this results in varying definitions in terms of what constitutes terrorism.

However, there is a highly contentious judgement of the Appeals Chamber of the Special Tribunal of Lebanon that has issued a landmark ruling that a 
definition of terrorism has emerged in international customary law consisting of three elements:

1. the perpetration of a criminal act (such as murder, kidnapping, hostagetaking, arson, and so on), or threatening such an act;

2. the intent to spread fear among the population (which would generally entail the creation of public danger) or directly or indirectly coerce a national or international authority to take some action, or to refrain from taking it;

3. when the act involves a transnational element. ${ }^{59}$

Interestingly, the joint Appeals Chamber of the ICTY and the International Criminal Tribunal for Rwanda (ICTR), essentially, came to the same judgement earlier in the 2006 Galic case; that is, that the prohibition of the use of terrorism against a civilian population was part of international customary law well before the Geneva Conventions were negotiated and ratified. This was confirmed by the ICTY through a number of cases; including: the 2001 Krstic case, and as mentioned, the 2006 Galic judgement, and the 2017 Mladic case, that there is a "crime of terror" and a "crime of persecution" which encompasses, terrorizing civilians. These judgements have marked a significant step forward with respect to defining the legal term "terrorism" in international criminal law. For instance, in the 2001 Krstic judgement, the ICTY ruled that the "crime of persecution" includes the "terrorizing of civilians." In the Stanislav Galic case, the defendant was specifically indicted on the charge of the "infliction of terror." In fact, Stanislav Galic, commander of the Bosnian Serb forces, became the first person to be convicted of the spreading of terror among the civilian population. In fact, the 2006 Galic case was the first case in which terrorism was considered as an autonomous war crime.

Ratko Mladic was the Chief of Staff of the Army of the Republika Srpska and was labelled the "Butcher of Bosnia" by the media. Among the many crimes that he was indicted for was the "Crimes Committed to Spread Terror among the Civilian Population of Sarajevo through a Campaign of Sniping and Shelling." Further, the Trial Chamber ruled that the "crime of terror" required the proof of the following three elements:

a) acts or threats of violence directed against the civilian population or individual civilians not taking direct part in hostilities causing the victims to suffer grave consequences;

59 Interlocutory Decision on the Applicable Law: Terrorism, Conspiracy, Homicide, Perpetration, Cumulative Charging, Case No. STL-11-o1/I (Feb. 16, 2011), https://www.stl-tsl.org/ en/the-cases/stl-11-01/main/filings/orders-and-decisions/appeals-chamber/534-fog36. (accessed February 11, 2018) 
b) the offender willfully made the civilian population or individual civilians not taking direct part in hostilities the object of those acts or threats of violence; and

c) the above acts or threats of violence were committed with the primary purpose of spreading terror among the civilian population. ${ }^{60}$

The Trial Chamber of the ICTY further ruled that the "crime of terror" was a violation of the laws and customs of war.

Simeon also considers three famous Supreme Court rulings on terrorism: the Canadian 2002 Suresh judgement; the UK, 2010JS (Sri Lanka) case; the US, 2010 Holder v. Humanitarian Law Project. All three cases deal with Sri Lankan appellants, at least in some part, and involve the Liberation Tigers of Tamil Eelam (LTTE), that are listed as a terrorist organization in each of these three countries. The respective Supreme Courts in these three jurisdictions upheld their governments' impugned legislation that were all challenged, in part, on substantive human rights and on procedural grounds.

The Supreme Court of Canada's Suresh judgement came to the conclusion that if a person who was determined to be refugee was properly found to be a "danger to Canada," then, they could be sent back, in exceptional circumstances, to a risk of torture and/or even death. This was an extraordinary judgement that came under heavy criticism internationally for apparently violating the international customary law principle of non-refoulement. In the JS (Sri Lanka) judgement of the UK Supreme Court, the LTTE was not accepted to be "predominantly a terrorist organization" and the focus was on the personal liability of the applicant and in order for the person to be excluded from refugee protection, the applicant had to have made a "voluntary" and a "significant contribution" to a terrorist action and activities. The US Supreme Court found the material support bar in the Holder v. Humanitarian Law Project to be constitutional and that it did not infringe on either the First or the Fifth amendments of the US Constitutional Bill of the Rights. The material support bar is, undoubtedly, one of the lowest standards for barring a refugee applicant from asylum in any jurisdiction.

Simeon concludes by calling upon the international community to address the gaps and shortcomings in international criminal law by ensuring that there is a universal standard for what constitutes terrorism in a non-war setting, consistent with what has emerged in international humanitarian law and that the variance in the definition of what constitutes terrorism at the national level is substantially reduced so that those who fall within Article $1 \mathrm{~F}$ of the ${ }^{1951}$

6o Prosecutor v. Ratko Mladic, Case No. IT-og-92-T, Judgement, Volumes III of V, 22 November 2017, p. 1663. http://www.icty.org/x/cases/mladic/tjug/en/171122-3of5_1.pdf. (accessed February 18,2018$)$ 
Convention relating to the Status of Refugees can be dealt with in a consistent and fair manner.

\subsubsection{Part Three}

The third section of this collection considers the national dimensions and dynamics of terrorism and exclusion from asylum that features four chapters. The first is Mark Symes's chapter on "Exclusion from Asylum on the Basis of Criminality - the United Kingdom's Response and its Broader International Law Context." This is followed by Barbara Kőhalmi and Anita Nagy-Nádasdi's contribution on Hungary titled, "Asylum-seekers as potential terrorists (?)," and, Nula Frei and Constantin Hruschka, consider the subject of "Caught Between Unworthiness and Exclusion: Asylum Applicants and Refugees Suspected of Terrorism in Swiss Law and Practice." The last chapter in Part Three covers Austria with Julia Kienast's contribution titled, "Forced Migration as a Security Threat: Challenging Criminalization Trends in Austria Under Presumed Links of Asylum and Terrorism."

Mark Symes offers an analysis of exclusion from refugee protection based on complicity in terrorist activities in the case law in the United Kingdom (UK). He points out that it is important to consider the legal environment to be able to understand the history of exclusion. The UK courts and tribunals draw heavily on other national courts and on international criminal law. In addition, the guidance of the UNHCR with respect to the application of the Exclusion Clauses is relevant and important. Here Symes makes reference to the UNHCR's Guidelines on International Protection: Application of the Exclusion Clauses: Article $1 F$ of the Convention relating to the Status of Refugees, paragraph 18 , that makes reference to "general individual responsibility from the person having committed, or have made a substantial contribution to the commission of the criminal act, in the knowledge that his or her act or omission would facilitate the criminal conduct." 61 The Exclusion Clauses incorporate international criminal law, specifically, within Article $1 \mathrm{~F}(\mathrm{a})$ and, it is argued, that two strands that are particularly significant are the Rome Statute and the decisions of the ad hoc Tribunals that interpreted the pre-existing body of international criminal law. The critical question that has yet to be resolved in international criminal law is what degree of complicity is necessary for criminal liability. The

61 UNHCR, Guidelines on International Protection: Application of the Exclusion Clauses: Article $1 F$ of the 1951 Refugee Convention relating to the Status of Refugees, 4 September 2003, p. 6, paragraph 18, https://www.unhcr.org/publications/legal/3f7 $448514 /$ guidelinesinternational-protection-5-application-exclusion-clauses-article.html. (accessed June 1, 2019) 
foundational principle of criminal responsibility, it is noted, is personal culpability. Symes further points out the UN Resolutions can also be a source of international law. He states that the series of UN Resolutions that were issued immediately after September 11, 2001, require States to address the incitement, the justification or glorification of terrorist acts, and calls on all "States to deny safe haven to any person who supports, facilitates, participates or attempts to participate in the financing, planning, preparation, or commission of terrorist act."62 The UN specifically calls on States to punish those who are liable for their intentional participation in terrorism.

The previous test for exclusion under Article $\mathrm{iF}$ relied on the Ramirez decision of the Federal Court of Appeal in Canada that stated that mere membership in a "limited and brutal purpose" organization, whose "aims, methods and activities were predominantly terrorist in character, [that] very little more would be necessary" to exclude the applicant. ${ }^{63}$ It is observed that IG Nepal was likely the high point in this approach that adopted the UNHCR formulation that where there is sufficient proof that the asylum seeker is a member of an international terrorist organization, such as those involved in the September 11, 2001 terrorist attacks, "voluntary membership could be presumed to amount to personal and knowing participation." 64

In time, this was set aside by the courts that favoured the personal culpability method. This leads Symes to undertake a detailed and thorough analysis of the JS (Sri Lanka) judgement of the UK Supreme Court and conclude by noting that the new test established was for a "knowing significant contribution to a criminal purpose." Subsequently, in Ezokola, the Supreme Court of Canada ruled that only a voluntary and significant contribution, in the knowledge that their conduct will further the crime and the criminal purpose, would be sufficient to exclude someone under Article $1 \mathrm{~F}$. The point was further made that,

The case law subsequent to Mbarushimana had held that conduct that merely might contribute to a crime or criminal purpose was insufficient; and the mental element excluded dolus eventualis (the awareness of a mere risk of prohibited consequences). ${ }^{65}$

62 UN Security Council Resolution 1368 (12 September 2001); Res/1624 (2005) (14 September 2005); Res/ 2178 (2014) (24 September 2014).

63 Ramirez v. Canada (Minister of Employment and Immigration), 1992 CanLII 8540 (FCA), [1992] 2 F.C. 306.

64 IG Nepal.

65 Prosecutor v.Jean-Pierre Bemba Gombo, ICC-01/05-01/08-424, Decision Pursuant to Article $61(7)$ (a) and (b) of the Rome Statute, 15 June 2009 (ICC, Pre-Trial Chamber II), at para. 360. 
It is concluded, by noting that even though liability is drawn broadly, it remains the case that guilt by association is not enough to found exclusion. Symes' notes that "the widening of the scope of potential liability is tempered by the requirement that there be an intensity of intention that is stronger than mere recklessness." Nonetheless, it is observed, that the "requirement for procedural rigour in the analysis of who falls for exclusion, combined with the requirement for a distinct level of contribution to the criminal purpose, remains an essential safeguard against overuse of the exclusion clauses."

Barbara Kőhalmi and Anita Nagy-Nádasdi's chapter on Hungary, titled, "Asylum-seekers as potential terrorists (?)," seeks to map out the nexus between asylum and terrorism and how terrorism has shaped the international refugee protection regime. They note that international law recognizes states' rights to security and the asylum-seekers' rights to security or protection from persecution as equal legitimate interests. They are, nonetheless, two competing interests and the right balance must be found through the application and interpretation of appropriate international and European laws. The balancing tests, Kőhalmi and Nagy-Nádasdi argue, generally, "require the comparison of different/opposite interests such as individual (right to protection) and community interests (right to security). States can strike the balance between the rights and restrictions differently, but the boundary of appreciation granted to a State is not unlimited." ${ }^{\prime 6}$ But, certain human rights can never be derogated from such as the right to life and the right to be free from torture or cruel and unusual treatment or punishment, and derogable rights can only be infringed according to human rights law. What is also indispensable is an independent judiciary to oversee this process and the necessity of ensuring that those whose rights have been infringed will have a right to challenge these decisions in the courts and have an effective remedy. And, finally, that international human rights must be given domestic effect through explicit protection in national legislation.

With respect to terrorism, Kőhalmi and Nagy-Nádasdi, rightly note that there is no comprehensive convention with a universal definition of what constitutes "terrorism." Accordingly, this only adds to the confusion surrounding the legal definition of what constitutes "terrorism." By the same token, they note that asylum also does not have a universally accepted definition and varies from region to region. The situation in Hungary for refugee applicants is that the linkage between terrorism and asylum has been made explicit by politicians and the media. For instance, the Hungarian Government placed a barbed

66 Barbara Kőhalmi and Anita Nagy-Nádasdi, "Asylum-seekers as potential terrorists (?)," p. 3 . 
wire fence on the Serbian-Hungarian border in an effort to stop illegal border crossing by migrants. At the same time, the Hungarian Criminal Code was amended in 2015 to make it illegal to cross the border fence. Anyone violating these provisions of the Hungarian Criminal Code would be subject to imprisonment and expulsion. They observe that this is perhaps the classic example of the criminalization of migration or "crimmigration." In September 2015, Hungary declared a state of emergency because of the mass influx of migrants. A declared state of emergency allows the police to enter private homes under suspicion without a warrant, taking real estate into state use, as well as mobile items owned or possessed by other state or municipal agencies, when none of the legally prescribed conditions are met. And, in 2016, the Hungarian Government amended the Fundamental Law to introduce a new type of state order, the "terror emergency situation," that allows for the use of extraordinary measures such as the use of the national army, tightened border controls, curfews, and the control of communications channels, etc., for the protection against terrorist attacks. Furthermore, the Hungarian Government's vigorous controversial billboard campaign opposed to migrants explicitly exemplified its anti-migrant policy stance.

Kőhalmi and Nagy-Nádasdi also note that the Hungarian asylum procedure became a single procedure on August 1, 2015, in which each relevant aspect of the asylum case under consideration, including any national security concerns, are considered by the asylum authority and its partner authorities, including, the Office of Constitutional Protection (OCP). The OCP has eight days to decide whether the asylum applicant is a national security threat. But, given the high abandonment and withdrawal rate for asylum applicants in Hungary, this procedure has proved to be administratively ineffective. Further, it is relevant to point out that the asylum authority can decide whether rejected applicants should be expelled or not.

The authors make reference to a number of interviews they undertook with noted non-governmental asylum authorities in Hungary regarding the nexus between terrorism and asylum. All those who were interviewed did not accept that there was any strong connection between the two terms. Consequently, Kőhalmi and Nagy-Nádasdi conclude, there is no demonstrable link between terrorism and asylum in Hungary, despite the Hungarian Government's hypervigilant policies to deflect refugees from its borders.

Nula Frei and Constantin Hruschka begin with the assertion that the public discourse narrative in Switzerland has not been too much affected by the mixing of "terrorism and asylum." The focus, rather, has been on the prevention of terrorism and the prevention of radicalization. Frei and Hruschka examine in detail the interlinkages between terrorism and asylum. They begin 
by considering those refugee claimants who fear being persecuted by terrorist groups such as the Islamic States (IS) that is known for targeting Yazidi and Christians in Syria and Iraq or internally displaced females without the protection of a clan or male family member are the target of extremist-terrorist groups like Al-Shabaab in Somalia, among others. They then go on to consider those who are excluded from refugee protection for their involvement in terrorist activities by noting that this very often requires a determination as to whether a person's affiliations and activities are, indeed, terrorist, and to decide whether there is sufficient evidence to conclude that the person was involved in such activities or had contributed in any way to terrorist activities. There are two ways in which a refugee claimant can be excluded from asylum under Swiss law: under Article $1 \mathrm{~F}$ of the ${ }_{1951}$ Convention relating to Refugee Status; and, for "unworthiness" under Article 53 of the Asylum Act, that excludes the person from asylum, but, with the recognition that the person is a refugee. Membership in an organization that has been declared "terrorist" may constitute a criminal offence under Article 260 of the Swiss Criminal Code. Frei and Hruschka state that according to the most recent developments in decision practice, "mere membership in an organization labeled as terrorist by the EU may be sufficient to exclude the person concerned from asylum." Under the "unworthiness" provisions of the Asylum Act, exclusion from refugee status is much broader than under Article $\mathrm{iF}$. The consequences of exclusion from refugee status is the person's refugee status claim will be rejected. The Federal Administrative Court (FAC) has the sole jurisdiction to review the judgements of the State Secretariat for Migration (SEM) in the Swiss asylum procedure. The SEM has to conduct the full investigation with regard to the exclusion clause as well as the person's refugee status, on the principle of "inclusion before exclusion," as recommended by UNHCR. Those who are found to be refugees due to a well-founded fear of persecution but are excluded will not be granted a provisional admission as a foreigner.

Frei and Hruschka, lay out in some detail, Article 53 of the Asylum Act, that stipulates refugee claimants will not be granted asylum: (a) if they are unworthy of asylum due to serious misconducted; (b) they have violated or endangered Switzerland's internal or external security; (c) they have been made subject to a criminal law expulsion order. The first two of these can be highly relevant for terrorists suspects seeking protection. The point is made that if the refugee is considered to be unworthy of asylum they will be recognized as refugees but will not be granted asylum and will, therefore, be issued an administrative expulsion order. But, because refugees are protected by nonrefoulement under Article 33(1) of the Refugee Convention and Article 25(2) of 
the Swiss Federal Constitution (SFC), the expulsion order will not be executed but, rather, replaced by provisional admission.

Frei and Hruschka conclude by stating that Swiss practice is that those who are seen to be "infected" by "terrorism" shall only be granted asylum if they are clear cut "victims of terrorism" or if the person can prove that they have been falsely perceived to be a terrorist. Those who are suspected of terrorism in Switzerland will not be issued a residence permit. The notion of "unworthiness" appears to play a large part in the assessment of whether the person is a "threat to the security of Switzerland." Mere suspicion of terrorist activity may be sufficient to bar a applicant to asylum, if they cannot prove non-involvement in terrorist activities. What Frei and Hruschka call a "purification exercise." They also argue that their analysis indicates the requirements for exclusion have been lowered significantly by the jurisprudence over the last decade. They end by stating that the legislative and judicial trend in Switzerland raises the question whether the "fight" against terrorism is really being advanced by the exclusion of terrorist suspects. It may be having an the reverse effect of radicalizing certain individuals in Switzerland. This leads them to conclude that "deradicalization" programs ought to be considered.

Julia Kienast explores the relationship between terrorism and asylum in Austria. She argues that both of these topics are mystified with many claims but little factual information. The resulting discourse and lack of transparency, she notes, are fertile soil for producing fear that is employed for the purposes of political mobilization. The actual correlation between terrorism and asylum is not seriously reflected upon in Austria. Accordingly, Kienast poses two specific questions: "What are the factual or perceived possible connections of the phenomena of terrorism and asylum? How do they influence Austrian asylum, and wider, migration law?"

In 2015, Austria, like many other European countries, received a mass influx of an estimated 600,000 to 800,000 irregular migrants that caused an overburdening of the reception system with the arrival of some 88,340 asylum applications. With the media's attention focussed on the so-called "asylum crisis" and the polarisation of Austrian society on the issue of migration, politicians immediately seized upon the issues. In the 2017 national elections, the issue of migration and security was still centre stage in the Austrian public's mind. In Austria, like other Western societies since 2001, the fear of terrorism is foremost in mind. Several forms of terrorist activity have been added to the Austrian Criminal Code, on several occasions, since 2002. And, there have been a number of prosecutions that have taken place since 2014 and mostly for preparatory acts such as financing terrorist organizations and incitement. Kienast's 
review and assessment of those forced migrants who are involved in terrorism indicates that the numbers are indeed small.

From the evidence available of those who are most susceptible to radicalization to terrorism in Austria are juveniles and those who are from the Chechen sub-culture. Nevertheless, Kienast further notes that this radicalization profile may change depending on the new demographics of forced migration since 2015. Effectively combatting radicalization efforts in Austria might better be served through integration measures rather than "isolation and stigmatization." There is also the problem of those who cannot be removed from Austrian territory due to their well-founded fear of persecution despite having been rejected from asylum. Their predicament can be, especially, trying given their precarious physical and psychological living conditions.

Kienast also considers various studies that examine the "fear of migration" that includes concerns about increasing crime rates, job shortages, and losing one's "national identity." Studies of security concerns among Austrians have found that 74 percent of citizens have a dread of the "continuous refugee stream." Indeed, Kienast points out that "migration is a heavily prejudiced phenomenon in many regards and, just like terrorism, it has a very 'intimate relationship' with fear." A 2017 IPSOS poll found that 59 percent of Austrians agreed with the statement, "There are terrorists that are pretending to be refugees who will enter my country to cause violence and destruction."

The dramatic increase in the number of irregular migrants travelling through Austria, along with the significant increase in asylum applications in 2014-15, leads Kienast to state that there was a "hysterical" legislative reaction of more than 80 amendments, not counting the underlying provisions of Union Law, to the Austrian asylum system. The three areas that were focused on were accelerated procedures, reduced workload of state agencies and the courts, and trying to reduce the misuse of asylum claims. And, specifically, in 2014 the asylum procedures were re-embedded in the administrative procedure and the Federal Office for Immigration and Asylum (BFA) that was given two tasks: the evaluation of asylum claims; and, the termination of residence. Amongst these legislative changes a new Integration Act was passed that required asylum applicants to learn German and to take an "Austrian values course." Further, social benefits were cut at both the federal and state levels. These rapid legislative amendments continue the trend of the "securitization of migration." For instance, persons were excluded from asylum on the mere suspicion of terrorism and an exception to the right of asylum was introduced for persons who "due to substantive reasons" are presumed to be a threat to national security due to "current events" and the threat posed by extremism and terrorism. In addition, the forced return of suspects of terrorism 
was allowed without exception to residence consolidation being taken into consideration.

Accordingly, Kienast concludes that the securitization of migration is experiencing a strong renaissance in Austria that amounts to a regression of the policies and practices of the 1990s. Moreover, it is argued that the "security narrative" is not a result of the unintentional consequence of two different but equally complex transactional issues, terrorism and asylum, but, rather the purposeful framing of asylum applicants and refugees as a general threat to national security and public order. This deliberately undermines the humanitarian perspective to achieve a political objective, the agenda of securitization of migration. What is being ignored and not pursued is a better understanding of the "root causes" of both terrorism and forced migration in order to develop realistic and sustainable strategies to address these serious concerns now and in the future.

From these summaries of the chapters of this edited volume it is evident that the connections between terrorism and asylum is evident across all societies and clearly manifested in international, transnational, and national laws. It is perhaps most evident among those states that were directly impacted by the 2015 refugee crisis in Southern Europe that were located directly in the path of the forced migrants as they made their way through Turkey and Greece and en route to Germany and other Northern European states. The impact of these tremendous numbers of forced migrants varied from state to state, but, the association between terrorism and asylum was evident across all states and fully exploited by right-wing political movements and governments to further their own political agendas. Nativism and the fear of the foreigner, the other, ran rampant in these societies and political leaders and legislators were hypervigilant in trying to address the perceived threat that came with this vast flow of humanity, that is, those who were thought to harbour evil intentions, including, terrorism whenever the opportunity might arise.

The exclusion from asylum of those responsible for serious international and national criminality is a built-in feature of the $195^{1}$ Refugee Convention, but, was not used extensively by States prior to 9/11. Indeed, it is not a commonly known feature of refugee protection, generally, that those who have committed a serious international or national crime or are guilty of actions that are contrary to the purposes and principles of the United Nations cannot be given refugee protection. 
The conceptual and normative dimensions of "terrorism" and "asylum" are confounded, in part, by the lack of a universally accepted definition of what constitutes "terrorism" or, indeed, for that matter what constitutes "asylum." There are different definitions of what is "terrorism" at the national level and there is no Comprehensive Convention on Terrorism at the international level because states cannot agree on what "terrorism" is because some states believe that it would limit or contradict the right to the self-determination of nations or be used against the leaders, civilian and military, of states that are engaged in legitimate armed conflict and warfare. The definition of who is a refugee varies from region to region with definitions that have expanded over time since the 1951 Refugee Convention such as the 1969 OAU Convention, the 1984 Cartagena Declaration, the 2011 EU Qualification Directive. The contested conceptual and normative bases of what constitutes "terrorism" and "asylum" contributes to the conflation of both of these terms. This makes these terms easy prey for those who wish to exploit them for their own use and purpose to advance their own political, economic, and social agendas. The legitimate exclusion of those who are responsible for terrorism is intended to include those who are directly or indirectly responsible for terrorist activities. The perpetrators of terrorism include those who commit the crime through their direct involvement and those who are complicit in the crimes as accessories and aid and abet the crimes through their indirect involvement. Both are equally guilt of the offence of terrorism. What is the extent of the extended liability to terrorism? This has ranged widely amongst states and over time at the international level. Joseph Rikhof has made a persuasive case for the adoption of common standards for extended liability across all levels, international, transnational and national, to ensure that the exclusion clauses are applied uniformly to ensure those who are criminally liable for terrorism are properly excluded from refugee protection. James Simeon equally makes the case for closing the gaps in international and national law with respect to what constitutes terrorism so that there is a common understanding of what constitutes terrorism for the purposes of exclusion from refugee protection as well as for the prosecution of those who are responsible for terrorist actions.

For a number of states, terrorism has had a serious impact on how they perceive forced migrants or refugees. This has been the case for the UK, Hungary, Austria, but, also Australia, the US, and other refugee receiving states. In fact, no states have been left untouched by terrorism, including, Switzerland. In all refugee receiving states, measures have been introduced to limit access to asylum to those suspected of terrorist activities. This is especially the case for both Austria and Hungary. Of course, following $9 / 11$ this would have been expected to be the case. Security measures have taken precedence and the fight to 
contain, if not defeat terrorism, has made this so. Moreover, terrorism and the threat of terrorism has been employed by political leaders to undertake measures that are likely to have the unintended consequence of radicalizing vulnerable youth who can then be easily manipulated into undertaking terrorist activities. Counter-terrorism measure should focus on protecting the human rights of all those seeking refugee protection rather than to limiting their access to asylum or to integrating fully in their host countries.

What follows then is an in-depth examination and analysis of the relationship between terrorism and asylum. Each of the authors in the accompanying chapters make an important contribution to understanding how these two concepts are interrelated and connected and how one has impacted on the other. We are most grateful for everyone's contribution to this edited volume. 